\title{
Neocortical Cell Migration: GABAergic Neurons and Cells in Layers I and VI Move in a Cyclin-Dependent Kinase 5-Independent Manner
}

\author{
Edward C. Gilmore ${ }^{1}$ and Karl Herrup ${ }^{1,2}$ \\ ${ }^{1}$ Department of Neurosciences, School of Medicine, Case Western Reserve University, and ${ }^{2}$ Alzheimer Research \\ Laboratory, University Hospitals of Cleveland, Cleveland, Ohio 44106
}

\begin{abstract}
The adult mammalian cerebral cortex arises from a complex series of neuronal migrations. The primitive layer known as the preplate is split into an outer marginal zone and an inner subplate by invading cortical plate neurons in an "inside-out" pattern of layering with respect to time of neuronal origin. In cyclin-dependent kinase 5 (Cdk5)-deficient mice (cdk5 $\left.{ }^{-l-}\right)$, the earliest born cortical neurons split the preplate, but later born neurons arrest below the subplate, resulting in an ectopic "outside-in" layer of neurons normally destined for layers II-V. We have pursued this analysis in cdk5 $5^{-1-} \leftrightarrow$ wild-type chimeric mice coupled with experiments in cell culture. In vitro migration assays show no difference in migrational ability between embryonic cdk $5^{-1-}$ and wild-type neurons. In $c d k 5^{-1-}$ chimeras, layers I and VI are made up of both mutant and wild-type
\end{abstract}

genotype neurons, whereas layers II-V contain predominantly wild-type cells. In addition, a thin layer of neurons is found below layer $\mathrm{VI}$, made up of $c \mathrm{dk} 5^{-/-}$cells; bromodeoxyuridine labeling suggests that these neurons were destined for layers II-V. Scattered cdk5 $5^{-\prime-}$ cells are found throughout layers II-V, but these neurons are always found to be GABAergic. The findings suggest that $C d k 5$ is not required for migration of either the deepest cortical plate neurons or the GABAergic neurons from the ganglionic eminences. The migration of layer II-V pyramidal neurons, however, is intrinsically blocked by Cdk5 deficiency, thus suggesting that different neuronal cell types use distinct mechanisms of migration.

Key words: tangential migration; radial migration; chimeras; cyclin-dependent kinase 5; BrdU; cortical cell culture
The cerebral cortex begins as a single layer of pseudostratified neuroepithelial cells and develops into a six-layered laminar structure (Boulder Committee, 1970). First the preplate, a layer consisting primarily of transient populations, forms. The preplate is split into two layers by radially migrating neurons destined to form the true cortical plate (Marin-Padilla, 1978). The first cohort of arriving neurons is followed by subsequent groups of cells that migrate past the subplate, past earlier born cortical plate neurons, and stop just under the marginal zone. The end result is a cerebral cortex that is born inside-out (Angevine and Sidman, 1961). Tangential migration of GABAergic interneurons from their ventricular origin in the ganglionic eminences adds additional complexity to the process (Anderson et al., 1997; Tamamaki et al., 1997).

The range of gene products whose coordinate expression is required during corticogenesis can be appreciated by considering the genetic defects, in both humans and rodents, that are known to disrupt this process. These mutations include the engineered null alleles of cyclin-dependent kinase 5 (Cdk5; Ohshima et al., 1996; Gilmore et al., 1998) and its activating subunit p35 (Chae et al., 1997; Kwon and Tsai, 1998). Cdk5 has close homology to other cyclin-dependent kinases, but its highest expression and levels of detectable activity are found within postmitotic neurons

\footnotetext{
Received Dec. 1, 2000; revised Aug. 9, 2001; accepted Aug. 16, 2001.

This work was supported by National Institutes of Health Grant NS20591. We thank Toshio Ohshima [Laboratory for Developmental Neurobiology, Brain Science Institute, The Institute of Physical and Chemical Research (RIKEN)] and Ashok Kulkarni (National Institute of Dental and Craniofacial Research, National Institutes of Health) for use of $c d k 5^{-1-}$ embryonic stem cells.

Correspondence should be addressed to Karl Herrup, Alzheimer Research Laboratory, University Hospitals of Cleveland, 10900 Euclid Avenue, Cleveland, OH 44106. E-mail kxh26@po.cwru.edu.

Copyright (ㄷ) 2001 Society for Neuroscience $\quad 0270-6474 / 01 / 219690-11 \$ 15.00 / 0$
}

(Hellmich et al., 1992; Lew et al., 1992; Tsai et al., 1993). Cdk5deficient mice develop normally through the point of early cortical plate neurons bisecting the preplate (Gilmore et al., 1998). Later born neuronal cohorts, however, appear unable to migrate past the subplate and form an outside-in layer located beneath the subplate; the mice subsequently die in the perinatal period (Ohshima et al., 1996, 1998, 1999; Gilmore et al., 1998). The proper migration of the earliest cortical plate neurons (layer VI) contrasts with the failure of later born immigrants to layers II-V and suggests that there are important differences between migratory programs of these two populations. This bipartite effect on migratory ability is not observed in reeler and related mutations, in which all neocortical neurons reside below the subplate (Falconer, 1951; Caviness and Sidman, 1973; Caviness and Rakic, 1978; Howell et al., 1997; Sheldon et al., 1997; Sheppard and Pearlman, 1997; Ware et al., 1997). Cdk5 may thus have a unique involvement in the migration of layer II-V neurons.

In this study, we demonstrate that $c d k 5^{-1-}$ neurons are fully competent to migrate in a simple culture model, in a manner indistinguishable from wild-type neurons. In contrast, we demonstrate that the in vivo radial migration of neurons in cerebral cortical layers II-V is Cdk5-dependent even in the relatively normal "terrain" of the Cdk5 chimera. Importantly, the tangential migration of the GABAergic interneurons from the ganglionic eminence is found to be Cdk5-independent. These findings imply differential requirements for migration by early and late cerebral cortical precursors, as well as by tangentially migrating GABAergic precursors.

\section{MATERIALS AND METHODS}

Migration assays. Cerebellar explant cultures were established from embryonic day 18 (E18) fetuses (plug date being E0). Pregnant $c d k 5^{+/-}$ dams from $c d k 5^{+1-}$ matings were killed by cervical dislocation, and their 
embryos were quickly removed into ice-cold HEPES-buffered saline solution. Heads were removed, and bodies were saved for PCR analysis (Ohshima et al., 1996; Gilmore et al., 1998). Tissue was dissected into small pieces, $\sim 50-150 \mu \mathrm{m}$ in diameter, in chilled HEPES-buffered saline solution. Five to eight pieces of tissue were placed into 24 well plates coated with poly-L-lysine (Sigma, St. Louis, MO) and laminin (Life Technologies, Gaithersburg, MD) containing Neurobasal medium (Life Technologies) supplemented with B-27 (Life Technologies), Penn-Strep at $100 \mathrm{U} / \mathrm{ml}$ (Life Technologies), and $2 \mathrm{~mm}$ L-glutamine (Life Technologies). Cultures were grown for $1 \mathrm{~d}$ before fixation. 4,6-Dimidino-2phenylindole (DAPI) staining was used to visualize cell nuclei. The location of cells relative to the explant edge was determined with $\mathrm{NIH}$ Image 1.6, and distances were calculated with Microsoft (Redmond, WA) Excel 98 software. Because cells do not uniformly migrate away from explants, photographs were taken at varying angles of $0,180,270$, or $90^{\circ}$ (in that order) from the center of the culture. The top of the plate was considered $0^{\circ}$. If no cells migrated away from an explant, it was not used for analysis.

Chimeric mice derived from $\mathrm{cdk} 5^{-1-}$ embryonic stem cells. $\mathrm{cdk} 5^{-1-}$ embryonic stem (ES) cell clones were obtained using the high G418 selection method (Mortensen et al., 1992). $c d k 5^{+/-}$ES cells, derived from clone 57 (Ohshima et al., 1996), were cultured in $1 \mathrm{mg} / \mathrm{ml} \mathrm{G} 418$ (Life Technologies) for 6-7 d. Resistant colonies were picked and genotyped individually as described previously (Ohshima et al., 1996, 1999). To generate chimeric mice, $c d k 5^{-1-}$ ES cells $(57 \mathrm{G} 23)$ were injected into blastocysts derived from C57BL/6 females mated with males from the ROSA26 transgenic strain. The cells of these animals contain a $\beta$-galactosidase transgene driven by a nearly ubiquitous cytomegalovirus promoter. As a result, histologically detectable expression of $\beta$-galactosidase is observed in nearly all cells, including neurons (Magrassi and Graziadei, 1996; Zambrowicz et al., 1997). Age-matched nonchimeric littermates, C57BL/6, and C57BL/6 $\times$ ROSA26 mice were used as controls.

Histological and immunohistochemical analysis. Adult brains from chimeras and controls were obtained after transcardial perfusion with $3 \%$

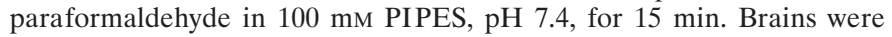
dissected and transferred overnight (or longer) to 20\% sucrose and PBS at $4^{\circ} \mathrm{C}$. For embryonic anti-GABA immunostaining, pregnant dams from $c d k 5^{+/-}$matings were killed at E18.5. Embryos were transferred immediately to cold PBS. Heads were transferred to $4 \%$ paraformaldehyde in $0.1 \mathrm{~mm}$ phosphate buffer for immersion fixation overnight at $4^{\circ} \mathrm{C}$ followed by transfer to $18 \%$ sucrose and PBS overnight (or longer) at $4^{\circ} \mathrm{C}$. Bodies were retained for PCR genotyping (Ohshima et al., 1996; Gilmore et al., 1998). Sections were cut on a cryostat at $12 \mu \mathrm{m}$. All sections were kept at $-70^{\circ} \mathrm{C}$ before use. For 5 -bromo-4-chloro-3-indolyl- $\beta$-D-galactoside (Xgal) studies, coronal sections of forebrain were incubated for $4 \mathrm{hr}$ at $37^{\circ} \mathrm{C}$ with $1 \mathrm{mg} / \mathrm{ml} \mathrm{X}$-gal in $35 \mathrm{~mm} \mathrm{~K}_{3} \mathrm{Fe}(\mathrm{CN})_{6}, 25 \mathrm{~mm} \mathrm{Fe}_{4}(\mathrm{CN})_{6}, 2 \mathrm{~mm} \mathrm{MgCl}_{2}$, $0.01 \%$ deoxycholic acid, and $0.02 \%$ Nonidet P-40 followed by several washes with $\mathrm{H}_{2} \mathrm{O}$. For bromodeoxyuridine (BrdU) immunostaining, sections were acid-permeabilized with $2 \mathrm{~N} \mathrm{HCl}$ for 75 min followed by neutralization with eight washes of PBS of 5 min each.

Immunocytochemistry was performed using primary antibody buffer consisting of PBS with $0.5 \%$ Tween 20 and $5 \%$ goat serum. The primary antibodies used and their dilutions were as follows: rat anti-BrdU (Accurate Chemicals, Westbury, NY), 1:6; rabbit anti-Cdk5 (Santa Cruz Biotechnology, Santa Cruz, CA), 1:100; rabbit anti-GABA (Sigma), 1:1000; mouse anti-NeuN (A60; a kind gift from Richard Mullen, Woods Hole Oceanographic Institute, Woods Hole, MA), 1:50; and mouse anti-calbindin (Sigma), 1:1000

Primary antibodies were visualized in PBS and $0.5 \%$ Tween 20 with $20 \%$ goat serum. The following secondary antibodies were used: goat anti-rat IgG conjugated to Cy3 (Chemicon, Temecula, CA), 1:400; goat anti-rabbit IgG conjugated to $\mathrm{Cy} 3$ (Jackson ImmunoResearch, West Grove, PA), 1:400; and goat anti-mouse IgG conjugated to FITC (Jackson ImmunoResearch), 1:200. Sections were counterstained with $1 \mu \mathrm{g} / \mathrm{ml}$ DAPI in PBS for $10 \mathrm{~min}$, followed by two washes in PBS for $5 \mathrm{~min}$.

Purkinje cell counts were performed on three nonadjacent midsagittal sections. Cresyl violet staining was performed on coronal sections of forebrain and sagittal sections of hindbrain according to standard protocols. Cerebral cortical neurons were counted under $400 \times$ magnification in a field $\sim 600 \mu \mathrm{m}$ in diameter for $\mathrm{Cdk} 5$ and NeuN double staining. For GABAergic staining, cells were examined with both light and fluorescent techniques and scored as $\beta$-galactosidase ( $\beta$-gal)-positive if they contained an X-gal deposit within or immediately adjacent to the neuron
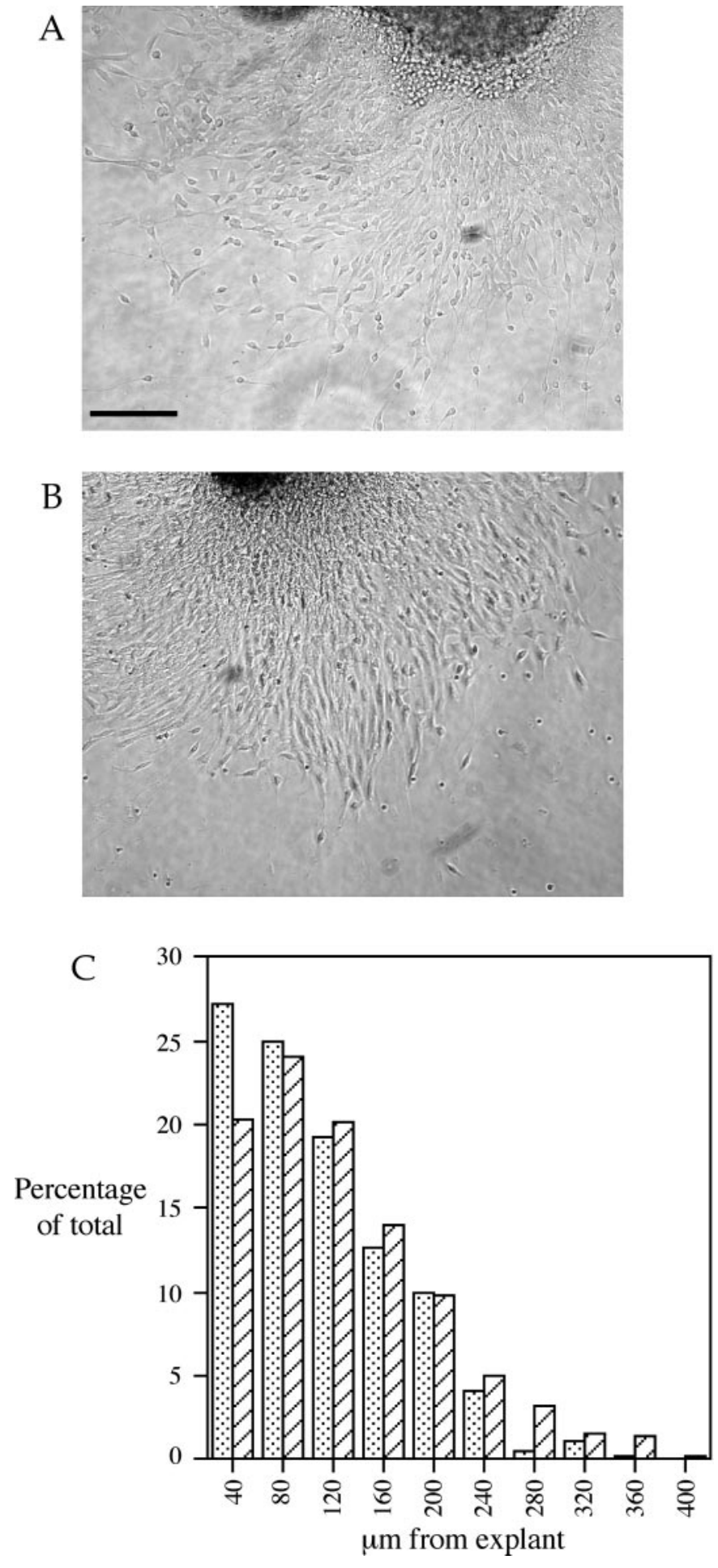

Figure 1. In vitro migration of cerebellar neurons on poly-L-lysine and laminin after $1 \mathrm{~d}$. Shown here are the cell migration patterns from explants of wild-type $(A)$ and $c d k 5^{-1-}(B)$ embryonic cerebellum. Processes consisting of radial glia and neurons are extended from the explants, and numerous migrating cells can be seen. No qualitative differences are seen between the two genotypes. $C$, Extent of migration represented as a frequency histogram of the distance migrated by granule cells from explant. The $y$-axis represents the relative percentage of neurons that traveled a particular range of distances. The $x$-axis represents the distance traveled from explant. The data for wild-type mice are represented by stippled bars; $c d k 5^{-1-}$ mice are represented by cross-hatched bars. No difference is seen between the genotypes. Scale bar, $100 \mu \mathrm{m}$. 


\begin{tabular}{|c|c|c|c|c|c|c|c|c|}
\hline Mouse & Wild type & $423 \mathrm{~A}$ & $423 \mathrm{~B}$ & $423 \mathrm{C}$ & $423 \mathrm{D}$ & $423 \mathrm{E}$ & Wild type & $326 \mathrm{~B}$ \\
\hline Age & Adult & Adult & Adult & Adult & Adult & Adult & $\mathrm{P} 12$ & P12 \\
\hline Counts & $671 \pm 23$ & $454 \pm 36$ & $637 \pm 32$ & $632 \pm 38$ & $458 \pm 49$ & $508 \pm 26$ & $441 \pm 40$ & $263 \pm 43$ \\
\hline Percent wild type & $100 \pm 5 \%$ & $68 \pm 5 \%$ & $95 \pm 5 \%$ & $94 \pm 6 \%$ & $68 \pm 7 \%$ & $76 \pm 4 \%$ & $100 \pm 9 \%$ & $60 \pm 10 \%$ \\
\hline
\end{tabular}

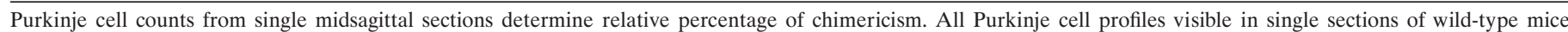

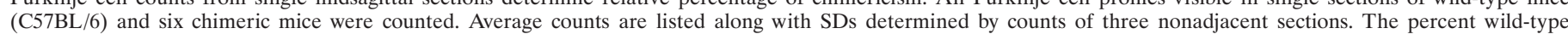
contribution and SD of an individual mouse was determined as a percentage of the Purkinje cell number of the age-matched wild type.
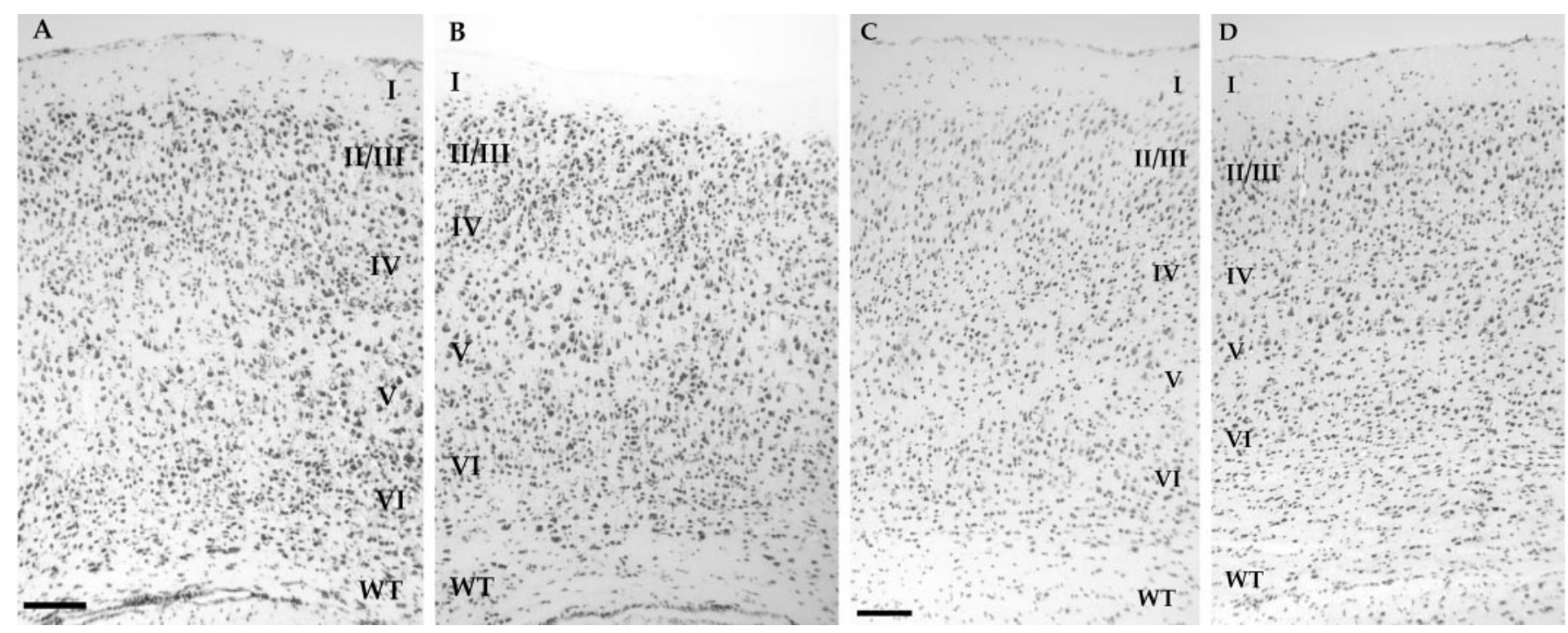

Figure 2. Cresyl violet-stained coronal sections of cerebral cortex. Both developing and mature cortex are illustrated here. $A$, Postnatal day 12 wild type; $B, \mathrm{Cdk} 5$ chimera $326 \mathrm{~B} ; C$, adult wild type; $D$, chimera 423D. Cortical layers are numbered $I-V I$ with the white matter tract $(W T)$ labeled along the ventral surface. Although different regions of cerebral cortex demonstrate variation in both composition and density of various layers of cells, the basic pattern is present in both wild-type and chimeric mice from early developmental times. Scale bar, $100 \mu \mathrm{m}$.

(see examples in Fig. 6). The boundaries of the six cortical layers were determined with DAPI or NeuN.

All sections were examined by standard light and fluorescent techniques on a Leitz (Wetzlar, Germany) Orthoplan microscope. Images were captured with a Spot digital camera model 1.3.0 from Diagnostic Instruments Inc.

Statistics. SD and Student's $t$ tests were performed using Microsoft Excel 98 software. The $\alpha$ value for the Student's $t$ test was always 0.05 .

\section{RESULTS}

The use of chimeric mice has greatly aided the study of many neurological mutations. Our laboratory has previously used this technique to analyze the developmental potential of the cerebellar cells in Cdk5-deficient mice. All $c d k 5^{-1-}$ Purkinje cells are blocked in their migration. This is true whether they are located in the mutant or in association with wild-type neighbors as in $c d k 5^{-1-} \leftrightarrow c d k 5^{+/+}$chimeric mice ( $\mathrm{Cdk} 5$ chimeras). In contrast, all genetically wild-type Purkinje cells migrate normally even in the chimera in the presence of mutant neighbors (Ohshima et al., 1999). There are also cell-autonomous defects in cerebellar granule cell migration, but these defects are not complete. Some $c d k 5^{-/-}$granule cells are capable of migrating from the external to the internal granule cell layer despite their mutant genotype. The cells of the deep cerebellar nuclei appear to migrate successfully regardless of their $c d k 5$ genotype (Ohshima et al., 1999).

\section{Cell migration assays}

We have shown that $\mathrm{Cdk} 5$ is required for proper migration of a number of neuronal progenitors in vivo (Gilmore et al., 1998;
Ohshima et al., 1999). The cell biological nature of this requirement, however, is not clear. To test for a potential defect in the general locomotive ability of mutant neurons, explants from the cerebella of E18 embryos derived from the mating of $c d k 5^{+/-}$ mice were grown in culture for $1 \mathrm{~d}$ before fixation. During this time, extensive neurite outgrowth and glial migration occurred along with significant neuronal migration away from the explants. There was no apparent difference between the number of granule cells that had migrated away from the explants in wild-type (Fig. $1 A)$ or $c d k 5^{-1-}$ (Fig. $1 B$ ) cultures. To estimate the rates at which the nerve cells migrate in vitro, their distance from the nearest edge of the explant after $1 \mathrm{~d}$ in culture was calculated. The results are shown in Figure $1 C$, and they illustrate that there was no difference between the genotypes in the distance traveled by individual neurons.

\section{Cerebral cortex of chimeras}

We have demonstrated previously that migrating cerebral cortical precursors in $c d k 5^{-/-}$mice migrate and properly split the preplate, but later born cerebral cortical precursors stall in their migration below the newly formed subplate (Gilmore et al., 1998). The perinatal death of the mutant embryos precludes the study of any late developmental event, including the completion of cortical cell migration. To address this, we generated $c d k 5^{-/-} \leftrightarrow c d k 5^{+/+}$ chimeric mice. Cdk5 chimeras survive into adulthood because of the presence of the wild-type cells, yet because all cell populations of these animals are made up mixtures of $c d k 5^{+/+}$and 

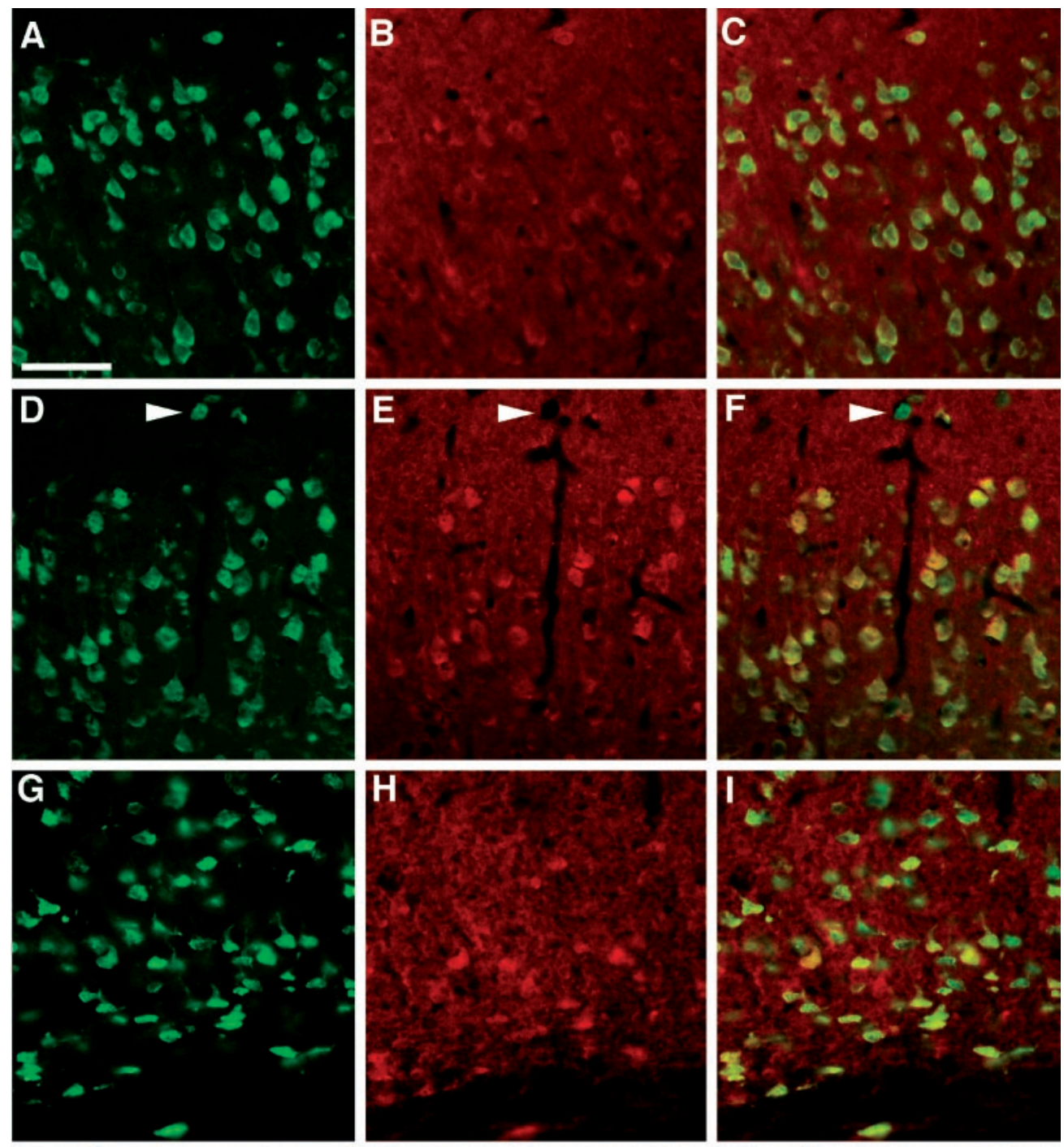

Figure 3. Immunostaining of cerebral cortex from wild-type mice ( $A-C$, superficial; $G-I$, deep) and Cdk5 chimeric mice $(D-F$, superficial; $J-L$, deep). Cdk5 immunostaining is shown in red (Cy3 secondary; $B, E, H, K$ ); the neuron-specific marker NeuN is shown in green (FITC secondary; $A, D, G, J$ ). $C, F, I, L$, digitally combined images. In layers II and III of both wild-type animals $(A-C)$ and chimeric animals, e.g., 426D $(D-F)$, most neurons are wildtype and thus Cdk5-positive. Double staining with NeuN antibody (green) demonstrates that nearly all of the neurons are $\mathrm{Cdk} 5$-positive, resulting in yellow when combined. There are excep-
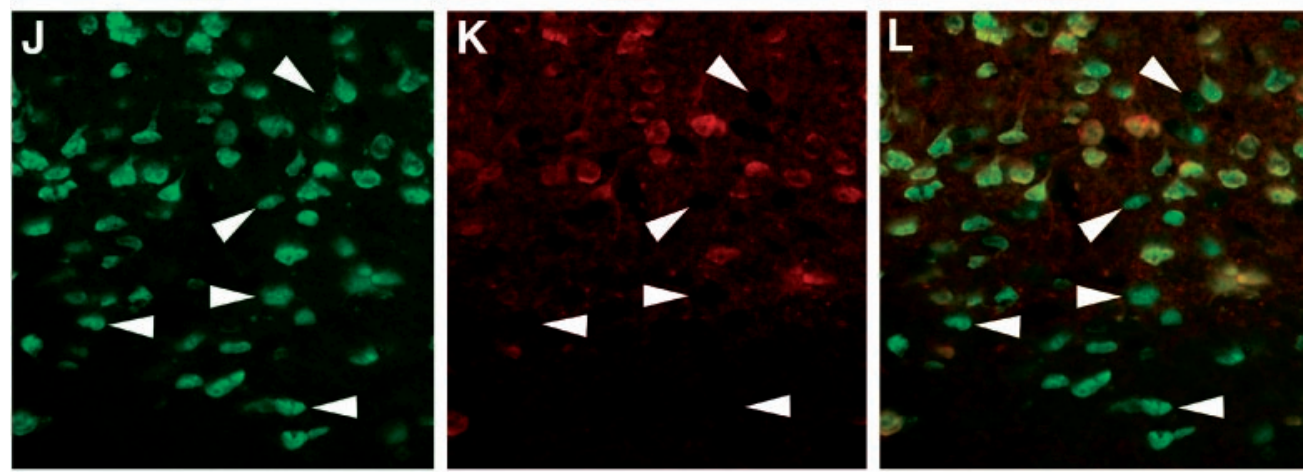
tions to this situation, however. The arrowhead in layer I of the Cdk5 chimera $(D-F)$ demonstrates a single $C d k 5^{-/-}$neuron within layer I. In deeper layers of cerebral cortex in wildtype animals $(G-I)$, all layer VI cells contain Cdk5. In contrast, neurons in the deeper regions of $\mathrm{Cdk} 5$ chimeras are often found to be $c d k 5^{-1-}$. The $a r$ rowheads in $J-L$ mark $c d k 5^{-1-}$ neurons within the deep portions of layer IV. The white matter tract contains occasional $c d k 5^{+/+}$neurons ( yellow) in both wild-type and Cdk5 chimeras. Scale bar, $50 \mu \mathrm{m}$.

$c d k 5^{-1-}$ cells, the resulting phenotype is both complex and highly informative. ES cells with both copies of the $c d k 5$ gene disrupted were injected into ROSA26 blastocysts. The neurons that descend from the cells of the host blastocysts will be wild type at the $c d k 5$ locus and, because of their ROSA genotype, each will express bacterial $\beta$-galactosidase (Magrassi and Graziadei, 1996; Zambrowicz et al., 1997). This genetic combination allows mutant and wild-type neurons to be distinguished on a cell-by-cell basis by two independent methods: wild-type neurons will express both $\mathrm{Cdk} 5$ and $\beta$-galactosidase, whereas mutant neurons will express neither.
The interpretation of the findings in chimeras such as these depends on the ability to determine the ratio of cells of the two genotypes. Because both the host embryos and ES cells were agouti, coat color could not be used. Instead we first examined the cerebellar parenchyma for misplaced Purkinje cells using calbindin staining to help identify the ectopic cells (results not shown) (Ohshima et al., 1999). To quantitate the degree of chimerism, we performed midline Purkinje cell counts of all animals. Within a chimera, the percentage of wild type in one tissue (i.e., cerebellum) closely follows the ratio of the genotypes in the rest of the animal (Soriano and Jaenisch, 1986). In addition, in the Purkinje 

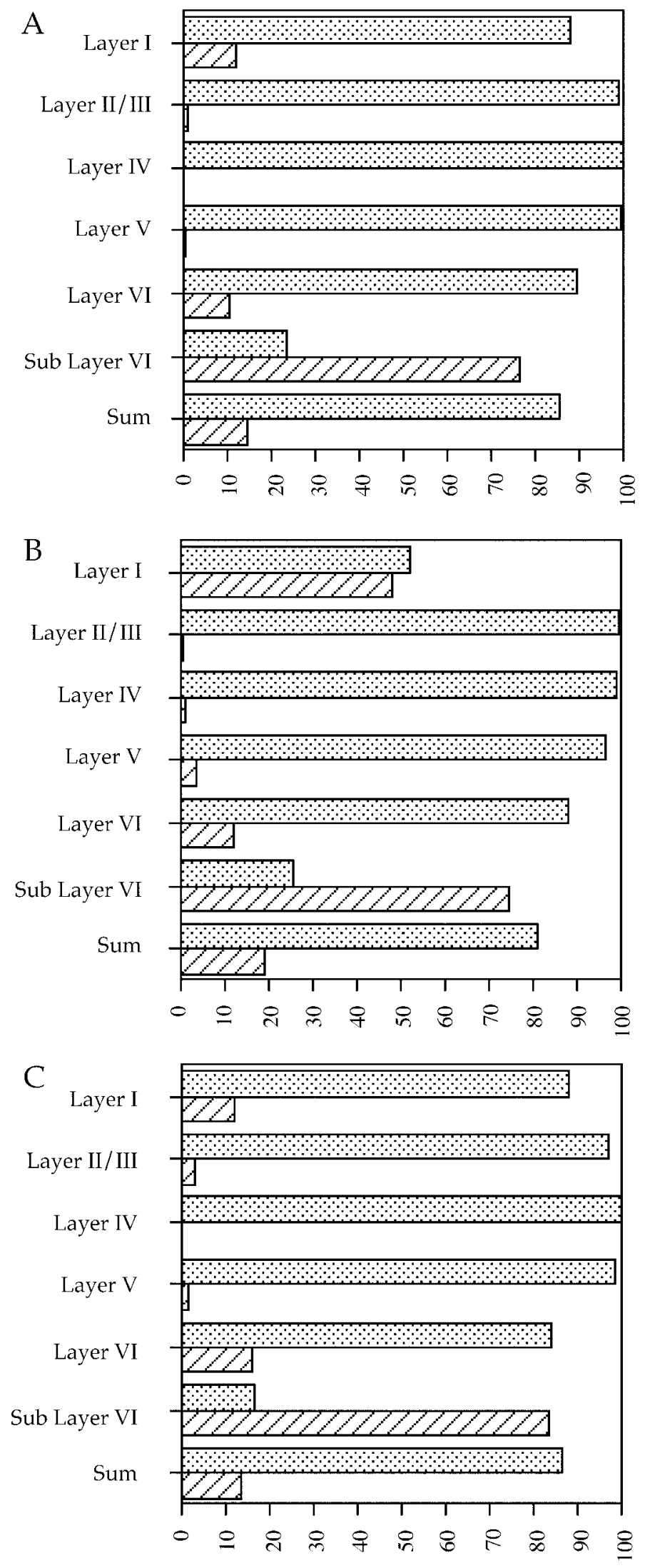

Figure 4. Graphic representation of data in Table 2. Results from chimera 423A are shown in $A$, chimera 423D in $B$, and chimera 326B in $C$. Stippled bars represent the percentage of wild-type neurons within that particular layer of cerebral cortex; cross-hatched bars represent the per- cell population, there is a fairly homogeneous distribution of the cells of the two genotypes across the two dimensions of the Purkinje cell layer (Mullen, 1977; Herrup and Sunter, 1987). Four Cdk5 chimeric mice were generated with estimated degrees of chimerism ranging from 60 to $76 \%$ wild type. Two potential chimeras, 426B and $426 \mathrm{C}$, had no ectopic $c d k 5^{-1-}$ Purkinje cells, indicating that they had essentially no $c d k 5^{-1-}$ contribution, and we have used them as wild-type, age-matched, littermate controls (Table 1).

Gross histological examination of $\mathrm{Cdk} 5$ chimeras indicated that the cytoarchitecture of their cerebral cortices were not dramatically different from wild-type (Fig. 2). Such variation as can be seen in Figure 2 cannot be distinguished from differences that might be expected on the basis of differences in either the anteroposterior or mediolateral location. Examination of animals at young postnatal (Fig. 2A,B) and adult (Fig. 2C,D) ages revealed similar cellular composition and density in both wild-type (Fig. $2 A, C$ ) and chimeric (Fig. $2 B, D$ ) mice; both contain the typical six-layer neocortical architecture. However, the density of cells in the subcortical white matter appears greater in the chimeras. This results in an apparent increase in the thickness of layer VI (Fig. $2 B, D$ ) compared with wild type (Fig. $2 A, C$ ).

Most of the chimeric cerebral cortex appears to be populated extensively by wild-type neurons, whereas most of the $c d k 5^{-/-}$ neurons are located below cortical layer V. Cdk5 is an abundant antigen that is highly expressed in all neurons, a fact that has been exploited previously in examination of the cerebellum of Cdk5 chimeras (Ohshima et al., 1999). In cerebral cortex of wild-type animals, all cells stained positive for the neuron-specific marker NeuN (Mullen et al., 1992) (Fig. 3A,G, green) and Cdk5 (Fig. $3 B, H$, red) and thus appear yellow when the two images are combined (Fig. 3C,I). A much different pattern is seen in Cdk5 chimeras. Layers II and III contain nearly all wild-type neurons, as indicated by the presence of both NeuN (Fig. 3D, green) and Cdk5 (Fig. 3E, red, F, yellow when photocombined), with a similar composition found in layers IV and V (results not shown). Layer I, on the other hand, contains a substantial number of $c d k 5^{-/-}$ neurons (white arrowhead) demonstrated by the presence of antiNeuN (Fig. 3D, green) and the absence of Cdk5 (Fig. 3E, red) resulting in a green appearance when photocombined (Fig. $3 F$ ). The $c d k 5^{-1-}$ neurons in layer VI have a similar staining pattern (Fig. 3J-L, white arrowheads). In addition, a substantial number of Cdk5-deficient neurons are found in deep portions of cerebral cortex, primarily in the white matter tract below layer VI (Fig. $3 J-L$, bottom-most arrowheads). These observations suggest that wild-type neurons are capable of proper migration within a chimeric environment, whereas most of the $c d k 5^{-1-}$ neurons are not. In every chimera we examined, however, there were always a few $c d k 5^{-/-}$neurons in layers II-V and many within layer I. To quantitate these observations, the genotype ratios of the different neuronal layers were determined by profile counts of NeuNlabeled cells. The raw counts are presented in Table 2, and the relative percentage of the genotypes in each layer is presented graphically in Figure 4. The essentially wild-type chimeras 423B centage of $c d k 5^{-/-}$neurons. Sum is all of the neurons from the various layers tallied together. Note the abundance of Cdk5-deficient neurons in Layer I, Layer IV, and Sub Layer VI compared with their near absence from the other layers. Note also that the number of $c d k 5^{-/-}$neurons within a layer is never zero. 


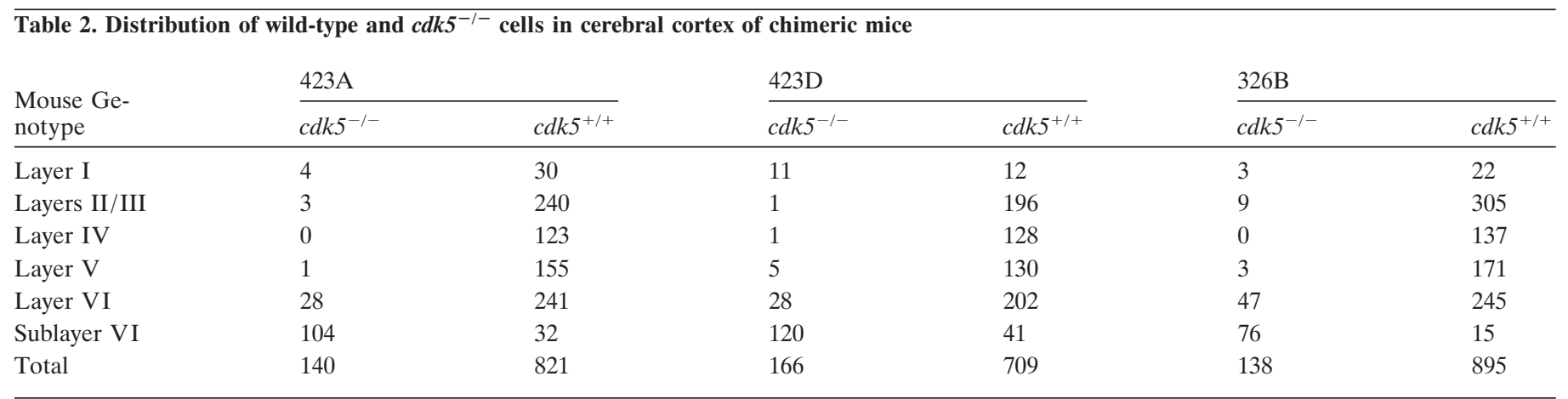

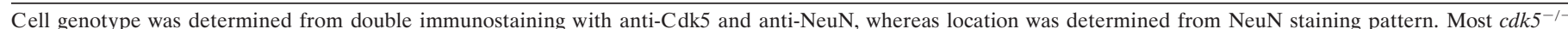

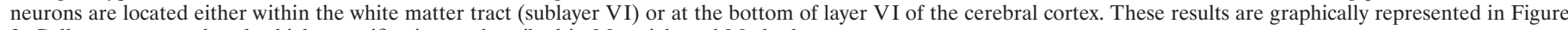
3. Cells were counted under high magnification as described in Materials and Methods.
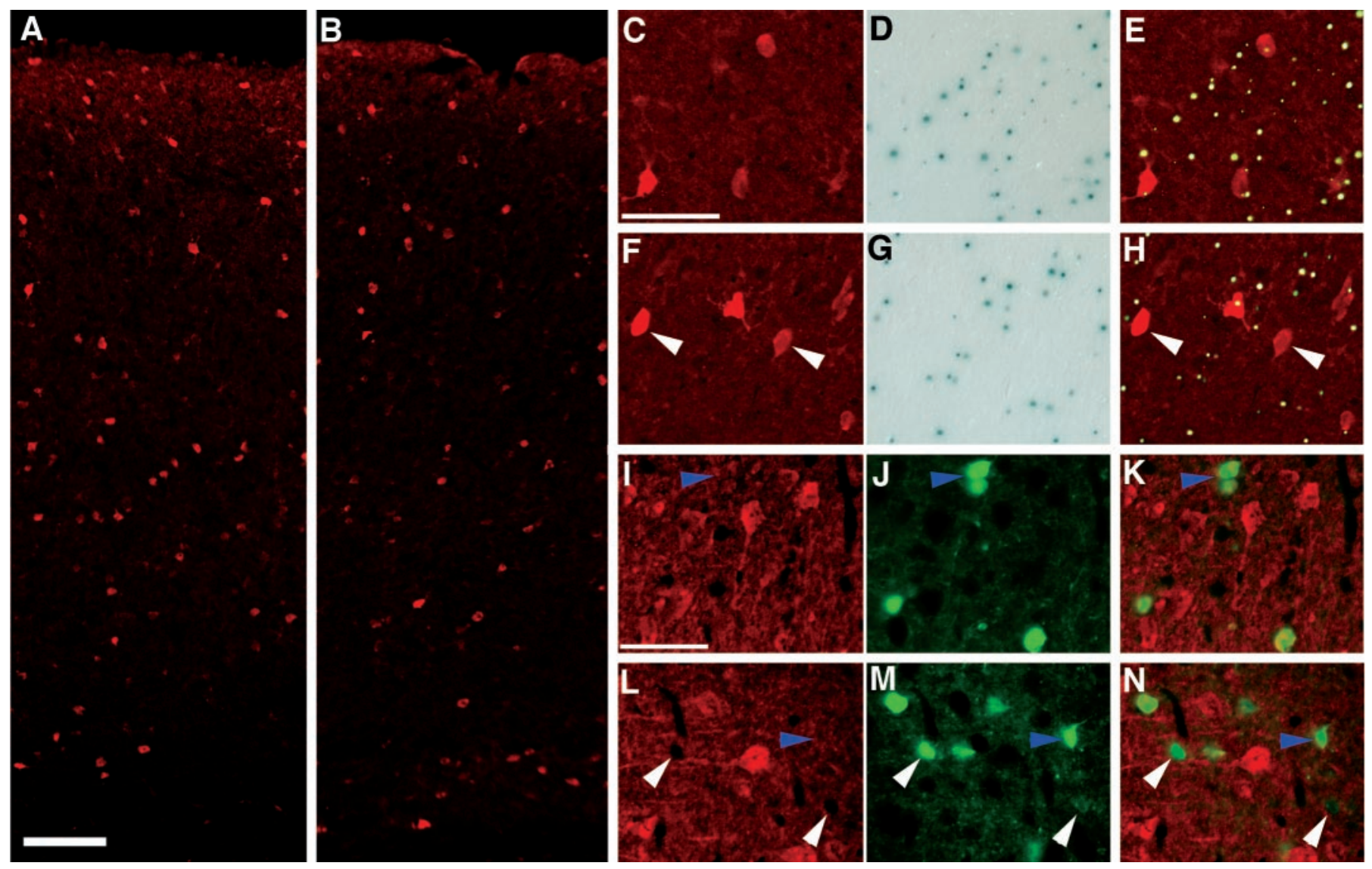

Figure 5. Cdk5-deficient GABAergic neurons are present within the cerebral cortex of Cdk5 chimeras. An essentially wild-type animal is shown in $A$, whereas a more balanced chimera is illustrated in $B$. Note the similar distribution of GABAergic cells in both animals. The remaining panels illustrate GABAergic immunostaining combined with X-gal histochemistry in wild-type $(C-E)$ and $\mathrm{Cdk} 5$ chimeric $(F-H)$ brains. Sections were stained with $\mathrm{X}$-gal $(D, G)$ and then were immunostained with anti-GABA antibodies (red; $C, F)$. The X-gal staining $(D, G)$ was digitally converted to green on a black background to allow overlay with GABA immunostaining for purposes of illustration $(E, H)$. A green dot is associated with all GABAergic neurons in the wild-type chimera $(E)$. In contrast, in Cdk5 chimeric mice $(H)$, many GABAergic neurons are X-gal-negative (arrowheads), indicating that they are $c d k 5^{-1-}$. To further confirm the presence of $c d k 5^{-1-}$ GABAergic neurons, wild-type $(I-K)$ and Cdk5 $(L-N)$ chimeras were double-labeled with antibodies to $\operatorname{Cdk} 5(I, L)$ and calbindin $(J, M)$, a marker for a subpopulation of GABAergic neurons (Hendry et al., 1989; Van Brederode et al., 1990). The images were digitally combined $(K, N)$ for clarity. In normal cortex $(I-K)$, all GABAergic neurons are Cdk5-positive (blue arrowhead). In the chimeric cortex $(L-N)$, although many of calbindin-positive neurons are also Cdk5-positive (blue arrowhead), there are substantial numbers of Cdk5-negative, calbindin-positive neurons (white arrowheads). Scale bars: $A, B, 100 \mu \mathrm{m} ; C-N, 50 \mu \mathrm{m}$.

and $\mathrm{C}$ and other controls were not counted, because these animals contained only $c d k 5^{+/+}$neurons.

Previous studies of cerebral cortex of $c d k 5^{-/-}$embryos indicated that only the earliest born cortical neurons are capable of entering the cortical plate, whereas the rest remain trapped below the subplate in the underplate (Gilmore et al., 1998). In Cdk5 chimeras, however, there are infrequent but regular examples of $c d k 5^{-1-}$ neurons found in layers II-V. We wished to determine the reason for this apparent discrepancy. Cortical plate neurons derive primarily from the ventricular zone of the dorsolateral 


\begin{tabular}{|c|c|c|}
\hline Mouse & $\beta$-Gal-negative (\%) & $\beta$-Gal-positive $(\%)$ \\
\hline $423 \mathrm{~A}$ & 23 & 77 \\
\hline $423 B$ & 7 & 93 \\
\hline $423 \mathrm{C}$ & 8 & 92 \\
\hline $423 \mathrm{D}$ & 40 & 60 \\
\hline
\end{tabular}

$\overline{\text { The percentage of } \beta \text {-gal-negative neurons and } \beta \text {-gal-positive neurons is shown as a }}$ percentage of total GABAergic neurons counted from cerebral cortex, not including layer I and white matter tract. $\beta$-Gal status was determined as described in Figure 4 and Materials and Methods. The percentage of $\beta$-gal-negative neurons is low in the essentially wild-type chimeras 423B and 423C (see Table 1). In contrast, in higher mutant chimeras 423A and 423D, the number of $\beta$-gal-negative neurons increases dramatically. This indicates that $c d k 5^{-/-}$neurons are contributing significantly to the GABAergic population of the cerebral cortex.

ventricle, but this is not their only source. The ganglionic eminences give rise to a large tangential migration of cells that are the likely precursors to the cortical GABAergic interneurons of cerebral cortex (de Carlos et al., 1996; Anderson et al., 1997; Tamamaki et al., 1997; for review, see Parnavelas, 2000). To determine whether $c d k 5^{-1-}$ cells in the upper layers of the chimeric cerebral cortex were these GABAergic neurons, immunostaining was performed with an anti-GABA antibody plus histochemical staining with X-gal for the genotype marker $\beta$-galactosidase. The spatial location of the GABA-positive neurons is the same in both wild-type mice (Fig. 5A) and all chimeras (Fig. $5 B$ ). An X-gal reaction product can be seen associated with most GABAergic neurons of the primarily wild-type chimera 423C (Fig. 5C-E), identifying them as $c d k 5^{+/+}$. Chimera 423D $\left(30 \% c d k 5^{-/-}\right.$; Table 1) has many more GABAergic neurons
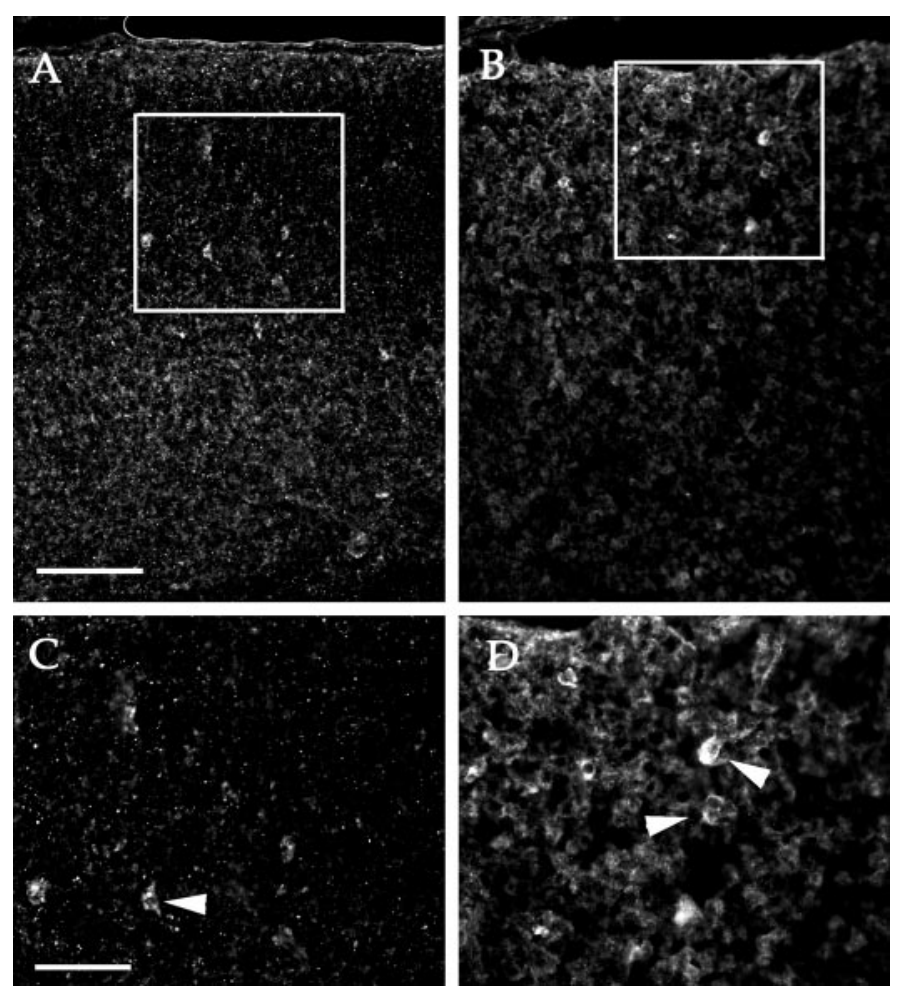

Figure 6. GABA staining is seen in both $c d k 5^{+/+}(A)$ and $c d k 5^{-/-}(B)$ E18.5 embryos. Insets in $A$ and $B$ are magnified in $C$ and $D$, respectively. Arrowheads indicate locations of GABA-positive neurons in highmagnification images $(C, D)$. Scale bars: $A, B, 100 \mathrm{~mm} ; C, D, 50 \mathrm{~mm}$. without associated X-gal staining (Fig. $5 F-H$, arrowheads). The presence of these $\mathrm{GABA}^{+} / \mathrm{X}$-gal ${ }^{-}$cells demonstrates that $c d k 5^{-1-}$ mutant GABAergic neurons survive and locate properly in the chimera. No pattern was noted in the mediolateral or anteroposterior location of $\beta$-gal-positive and -negative neurons, indicating that both $c d k 5^{+/+}$and $c d k 5^{-/-}$neurons are equally capable of migrating throughout the cerebral cortex.

To quantitate this effect, GABAergic neurons were counted and scored for the presence of X-gal precipitate. The results are shown in Table 3. The percentage of $\mathrm{GABA}^{+} / \mathrm{X}-\mathrm{gal}^{-}$neurons is $7 \%$ for $423 \mathrm{~B}$ and $8 \%$ for $423 \mathrm{C}, 23 \%$ for $423 \mathrm{~A}$, and $40 \%$ for $423 \mathrm{D}$. The essentially wild-type mice, $423 \mathrm{~B}$ and $\mathrm{C}$, having 7-8\% $\mathrm{GABA}^{+} / \mathrm{X}$-gal ${ }^{-}$, likely represent the false-negative rate, whereas the chimeric animals $423 \mathrm{~A}$ and $\mathrm{D}$ have percentages that correspond approximately to the level of chimerism in these animals (Table 1). To confirm that $c d k 5^{-1-}$ GABAergic neurons exist within the $\mathrm{Cdk} 5$ chimeric cerebral cortex, calbindin and Cdk5 double immunostaining was performed (GABA and Cdk5 double immunostaining could not be performed because of antibody incompatibility). Calbindin labels a subset of GABAergic neurons within the cerebral cortex (Hendry et al., 1989; Van Brederode et al., 1990; Gogelia and Hamori, 1992). In the essentially wild-type mouse, 423C, all calbindin-positive neurons were $\mathrm{Cdk} 5$ positive (Fig. 5I-K, blue arrowhead). However, whereas the chimeric mouse, 423D, also contained Cdk5-positive neurons (Fig. $5 L-N$, blue arrowhead), this animal also had numerous $\mathrm{Cdk} 5$ negative, calbindin-positive neurons (white arrowheads) in its cortex. This is additional evidence for the presence of Cdk5negative GABAergic neurons within the cerebral cortex of this animal.

To confirm the ability of $c d k 5^{-/-}$GABAergic neurons to migrate properly, we examined both wild-type and $c d k 5^{-1-}$ nonchimeric embryos. In E18.5 cerebral cortex, anti-GABA immunostaining is qualitatively distinct but quantitatively low compared with other brain regions (results not shown). This situation is true in both wild-type (Fig. 6A) and $c d k 5^{-/-}$(Fig. 6B) animals. In E18.5 wild-type embryos, GABAergic neurons are found within deeper portions of the developing cerebral cortex [Fig. $6 \mathrm{~A}$, inset (magnified area of $D$ ), $D$ ] (Del Rio et al., 1992). GABAergic neurons are also found in the portion of the $c d k 5^{-1-}$ cortex that contains the early cortical plate (between the marginal zone and subplate, $\sim 50 \mu \mathrm{M}$ below the pial surface; Gilmore et al., 1998) [Fig. 6B, inset (magnified area of $D$ marked by arrowheads)]. These data validate the evidence from the $\mathrm{Cdk} 5$ chimeras that GABAergic neurons do not require Cdk5 activity for proper migration.

Our findings demonstrate that most $c d k 5^{-1-}$ neocortical neurons are deficient in their migration, but the complete status of wild-type neurons remains unknown. We have already shown that the chimeric cerebral cortex appears normal in its overall appearance and layering pattern (Fig. 3) and that it is composed of primarily wild-type neurons (Table 2, Fig. 4). It remains a possibility, however, that some $c d k 5^{+/+}$neurons are disrupted in their migration by the presence mutant neurons during development. To investigate the migration of a particular population, the nucleoside analog BrdU was injected into pregnant dams at day 17 of gestation. Cortical neurons born at this time normally migrate to layers II and III in the mouse (Caviness, 1982; Nowakowski et al., 1989). Anti-BrdU immunostaining of adult wild-type animals treated in this way during their gestation reveals that most of the neurons labeled with BrdU are indeed found within layers II and 

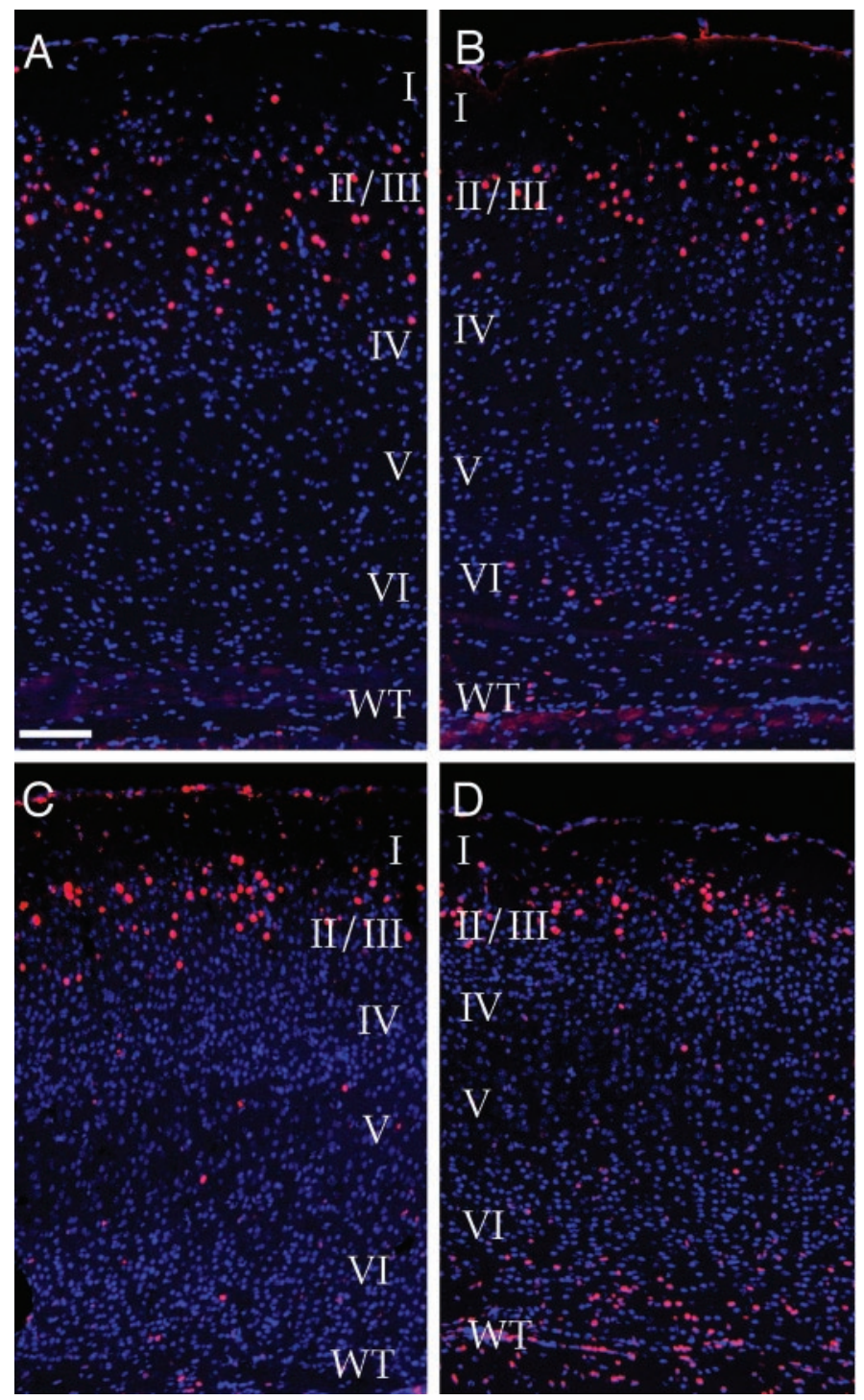

Figure 7. Migration of $c d k 5^{-1-}$ neurons is defective in the Cdk5 chimera. Wild-type $(A, C)$ and chimeric $(B, D)$ mice were labeled with BrdU at E17.5. Superimposed images of DAPI (blue) and anti-BrdU (red) staining are shown. BrdU-labeled neurons appear purple. In wild-type adult $(A)$ and juvenile (postnatal day $12 ; C$ ) mice, most of the E17-labeled neurons settle in layers II and III as expected (Caviness, 1982). In chimeras, many E17-labeled neurons end up in layers II and III, but a number are found deep to these layers as well. Similar results are found in both young $(D)$ and old $(B)$ animals. Note that small nuclei, faintly stained with BrdU, are present throughout the cortex. Because of their small size, they are likely to be glial cells. Scale bar, $100 \mu \mathrm{m}$.

III (Fig. 7A). Interestingly, although many labeled neurons are also found in layers II and III in the chimera, many BrdU-labeled neurons remain in deep portions of cerebral cortex below layer VI (Fig. 7B) where $c d k 5^{-1-}$ neurons are found (Fig. 4, Table 2). A similar result was found in young (postnatal day 12) chimeras (Fig. 7C,D). Younger chimeras also display small, faintly stained BrdU-positive nuclei throughout the cerebral cortex. These nuclei are likely to belong to glial cells, because glial genesis begins approximately at the time of BrdU injection. We presume that the few large BrdU-labeled neurons not found within layers II and III or IV are likely to be GABAergic neurons, which are also born at this time (Miller, 1986).

\section{DISCUSSION}

The present analysis extends our previous studies of the defects in neuronal migration of Cdk5-deficient neurons. We find that neurons do not seem to require $\mathrm{Cdk} 5$ activity for simple migration activities in vitro. This is in contrast to other mutants in which sometimes subtle defects in migration in vivo display dramatic in vitro migration difficulties (Rezai and Yoon, 1972; Hatten et al., 1986; Reiner et al., 1993; Hirotsune et al., 1998). If Cdk5 deficiency worked in this manner, we would expect to find slowermigrating cells in our cultures from mutant cerebral cortex. Although it is theoretically possible that only Cdk5-independent neurons migrate away from the explants, we observed no difference between $c d k 5^{-1-}$ and wild-type explants in either the pattern or extent of cell movement. As a whole, our results suggest that $\mathrm{Cdk} 5$ is not an essential part of the basic movement machinery of a cell but instead plays a specific role in the much more complicated process of directed neuronal migration in vivo.

Chimeric animals are a powerful system in which to examine the adult cellular phenotypes of mutants that die during development and to determine how wild-type and mutant cells interact. Previous analysis of $c d k 5^{-1-}$ embryos demonstrated that early cortical plate precursors (layer VI) and preplate neurons do not require $\mathrm{Cdk} 5$ to migrate properly, whereas all other cortical plate neurons do (Gilmore et al., 1998). Analysis of the chimeras indicates that the $\mathrm{Cdk} 5$ deficiencies are cell-autonomous defects in migration. Most of the neurons in the cerebral cortex of the adult chimeras are wild-type, whereas most of $c d k 5^{-/-}$cells are located ectopically at the bottom of the cerebral cortex. Examination of the cerebral cortex of $\mathrm{Cdk} 5$ chimeras also reveals the presence of mutant $\left(c d k 5^{-/-}\right)$GABAergic neurons within the cerebral cortex. We conclude from this that Cdk5 activity is not required for proper migration of GABAergic neurons from ganglionic eminences into and throughout the cerebral cortex (de Carlos et al., 1996; Anderson et al., 1997; Tamamaki et al., 1997; for review, see Parnavelas, 2000).

Within $c d k 5^{-1-}$ mutant embryos, only the earliest born cortical neurons are capable of migrating through the subplate and separating it from the marginal zone (Gilmore et al., 1998). In the chimeras, many $c d k 5^{-/-}$neurons are found mixed with their wild-type counterparts within the deep strata of layer VI. It is possible that some of these are true layer VI cells, because in both the mutant and the chimera they migrate past the subplate and separate it from the marginal zone, thus establishing a bona fide cortical plate. It is also possible that, during normal development, some neurons from the embryonic subplate survive into adulthood and become located in the deep portions of layer VI, as suggested by Landry et al. (1998). In addition, $c d k 5^{-1-}$ GABAergic neurons deep within the cortex can be confused with layer VI neurons. However, we think that our evidence supports the conclusion that the $c d k 5^{-/-} \mathrm{NeuN}^{+}$cells are true layer VI neurons for two reasons. First, some $c d k 5^{-/-}$neurons are located in more superficial portions of this layer, an unlikely position for surviving subplate neurons. Second, in the mutant Cdk5-deficient embryos, there is a distinct population of layer VI-like neurons that separate the subplate from the marginal zone. Proper migration of $c d k^{-/-}$layer VI neurons within Cdk5-deficient mice is in contrast to the situation in the reeler mouse, in which such cells are absent, and this crucial event in corticogenesis never occurs (Gilmore et al., 1998).

We have proposed previously, on the basis of the phenotype of the $c d k 5^{-1-}$ embryo, that layer VI neurons use a different mech- 
anism of migration than do neurons in layers II-V (Gilmore et al., 1998). We suggested that layer VI neurons might use a Cdk5independent mechanism to translocate their nucleus through a cytoplasmic process that remains attached to the pial surface, a mechanism that has been proposed previously (Morest, 1970; Nowakowski and Rakic, 1979; Brittis et al., 1995). We also speculated that radial glial-guided migration (Rakic, 1971a,b, 1972) might be used by the subsequent neurons of layers II-V. Recent studies by Nadarajah et al. (2001) using slice culture visualization of migration have found new evidence in support of this model. Early precursors appear to move their cell body in a manner consistent with nuclear translocation (Nadarajah et al., 2001). GABAergic neurons not only migrate from the ganglionic eminences and through the subventricular zone of the cerebral cortex, they must at some point more deeply penetrate the superficial cortical plate region of cerebral cortex. Because this process appears unaffected by the absence of Cdk5, GABAergic neurons must use different cues or different migrational mechanisms than layer II-V neurons to reach their final location.

The cell-autonomous requirement for $\mathrm{Cdk} 5$ shows some similarities to other mouse mutants. Reeler mice are deficient in the large extracellular protein reelin. This protein is thought to bind to several different extracellular receptors, resulting in the differential phosphorylation of the mouse disabled protein mDab1 (D’Arcangelo et al., 1995, 1997, 1999; Hirotsune et al., 1995; Ogawa et al., 1995; Howell et al., 1997, 1999; Sheldon et al., 1997; Ware et al., 1997; Rice et al., 1998; Hiesberger et al., 1999; Senzaki et al., 1999; Trommsdorff et al., 1999) (for review, see Rice and Curran, 1999; Gilmore and Herrup, 2000). Cerebellar Purkinje cells appear to require intrinsic Dab1, because all Dab1 $1^{-1-}$ Purkinje cells in Dab1 chimeras are blocked in their migration (Goldowitz, 1998). Correct migration would also appear to require a certain level of cell-cell interaction, however, because some wild-type Purkinje cells remain ectopically located in Dab1 chimeras that are made up primarily of mutant cells (D. Goldowitz, personal communication). In addition, recent evidence demonstrates a genetic association between Dab1 and the Cdk5 activator p35 (Ohshima et al., 2001). The exact relationship between reelin and Dab1 and $\mathrm{p} 35$ and $\mathrm{Cdk} 5$ for proper migration is clearly a matter that requires further study.

The survival of substantial numbers of mutant cells in the mature chimeras indicates that $\mathrm{Cdk} 5$ deficiency per se is not toxic to neurons. GABAergic neurons of the cerebral cortex, Purkinje cells, deep cerebellar nuclear neurons, granule cells, and nearly all neurons in the embryo can survive without Cdk5, although precise quantitation has not been performed for any population (Gilmore et al., 1998; Ohshima et al., 1999). Nonetheless, in the chimera, $c d k 5^{-1-}$ neurons appear to be at a significant long-term survival disadvantage compared with wild-type neurons. Estimations of the percent chimerism from wild-type Purkinje cell counts can be used to illustrate that the percentage of $c d k 5^{-/-}$ neurons present in the cerebral cortex is much lower than would be predicted (Tables 1, 3). For 423A, the observed percentage is $15 \%$, whereas the expected percentage is $32 \%$; for $423 \mathrm{D}, 19 \%$ is the observed percentage, whereas $32 \%$ is expected. For chimera $326 \mathrm{~B}$, the numbers are even more dramatic. On the basis of the Purkinje cell counts, $40 \%$ of the cells of cerebral cortex should be mutant, yet we observed only $14 \% c d k 5^{-1-}$ cells. The three animals combined have a lower than expected percentage of $c d k 5^{-1-}$ neurons that is statistically significant $(p<0.005)$. These calculations strongly suggest that $c d k 5^{-1-}$ neurons are selected against during development. It is noteworthy that the counts of Cdk5-deficient neurons include the GABAergic neurons present in each field; therefore, the deficiency of neurons derived from the telencephalic ventricular zone is most likely even greater than these approximate calculations would imply. The missing cells cannot be explained by a deficit in the generation of $c d k 5^{-1-}$ neurons, because no detectable difference in the size of cerebral cortex is noted between $c d k 5^{-1-}$ and wild-type embryos at E18.5 (Ohshima et al., 1996; Gilmore et al., 1998).

Why $c d k 5^{-1-}$ neurons should be at such a competitive developmental disadvantage is not clear. Ectopic location alone does not prevent a neuron from finding a target. Significant neuronal ectopia has been observed in other mouse mutants such as reeler, scrambler $\left(d a b 1^{-1-}\right)$, and the null allele of the Cdk5 activator p35; these displacements have no reported effect on cell survival within the cerebral cortex. In addition, characterization of the reeler mutant has shown repeatedly that mispositioned neurons are fully capable of finding their correct target (Lemmon and Pearlman, 1981; Simmons et al., 1982; Caviness and Frost, 1983; Frost et al., 1986) even if the time course of connectivity is delayed compared with wild type (Yuasa et al., 1994; Del Rio et al., 1997). If ectopic $c d k 5^{-/-}$neurons were delayed in finding a target in chimeras, that could put them at a competitive disadvantage compared with wild type. This situation may be amplified further, because Cdk5 has been suggested to be important for normal axonal outgrowth and synaptogenesis (Matsubara et al., 1996; Nikolic et al., 1996, 1998; Xiong et al., 1997; Paglini et al., 1998; Qi et al., 1998; Shuang et al., 1998; Fletcher et al., 1999). Thus, lack of survival of $c d k 5^{-/-}$neurons could be attributable to migrational, axonal, or synaptic defects, or to an interaction of all three.

\section{REFERENCES}

Anderson SA, Eisenstat DD, Shi L, Rubenstein JL (1997) Interneuron migration from basal forebrain to neocortex: dependence on Dlx genes. Science 278:474-476.

Angevine JB, Sidman RL (1961) Autoradiographic study of cell migration during histogenesis of cerebral cortex in mice. Nature 192:766-768.

Boulder Committee (1970) Embryonic vertebrate central nervous system: revised terminology. Anat Rec 166:257-261.

Brittis P, Meiri K, Dent E, Silver J (1995) The earliest patterns of neuronal differentiation and migration in the mammalian central nervous system. Exp Neurol 134:1-12.

Caviness Jr VS (1982) Neocortical histogenesis in normal and reeler mice: a developmental study based upon $\left[{ }^{3} \mathrm{H}\right]$ thymidine autoradiography. Dev Brain Res 4:293-302.

Caviness Jr VS, Frost DO (1983) Thalamocortical projections in the reeler mutant mouse. J Comp Neurol 219:182-202.

Caviness VS, Rakic P (1978) Mechanisms of cortical development: a view from mutations in mice. Annu Rev Neurosci 1:297-326.

Caviness Jr VS, Sidman RL (1973) Time of origin or corresponding cell classes in the cerebral cortex of normal and reeler mutant mice: an autoradiographic analysis. J Comp Neurol 148:141-151.

Chae T, Kwon YT, Bronson R, Dikkes P, Li E, Tsai L-H (1997) Mice lacking p35, a neuronal specific activator of $\mathrm{Cdk} 5$, display cortical lamination defects, seizures, and adult lethality. Neuron 18:29-42.

D'Arcangelo G, Miao GG, Chen SC, Soares HD, Morgan JI, Curran T (1995) A protein related to extracellular matrix proteins deleted in the mouse mutant reeler. Nature 374:719-723.

D'Arcangelo G, Nakajima K, Miyata T, Ogawa M, Mikoshiba K, Curran $T$ (1997) Reelin is a secreted glycoprotein recognized by the CR-50 monoclonal antibody. J Neurosci 17:23-31.

D'Arcangelo G, Ramin H, Keshvara L, Rice D, Sheldon M, Curran T (1999) Reelin is a ligand for lipoprotein receptors. Neuron 24:471-479.

de Carlos JA, Lopez-Mascaraque L, Valverde F (1996) Dynamics of cell migration from the lateral ganglionic eminence in the rat. J Neurosci 16:6146-6156.

Del Rio JA, Soriano E, Ferrer I (1992) Development of GABAimmunoreactivity in the neocortex of the mouse. J Comp Neurol 326:501-526.

Del Rio JA, Heimrich B, Borrell V, Forster E, Drakew A, Alcantara S, Nakajima K, Miyata T, Ogawa M, Mikoshiba K, Derer P, Frotscher M, 
Soriano E (1997) A role for Cajal-Retzius cells and reelin in the development of hippocampal connections. Nature 385:70-74.

Falconer DS (1951) Two new mutants, "trembler and reeler," with neurological actions in the house mouse. J Genet 50:192-201.

Fletcher AI, Shuang R, Giovannucci DR, Zhang L, Bittner MA, Stuenkel EL (1999) Regulation of exocytosis by cyclin-dependent kinase 5 via phosphorylation of munc18. J Biol Chem 274:4027-4035.

Frost DO, Edwards MA, Sachs GM, Caviness VS Jr (1986) Retinotectal projection in reeler mutant mice: relationships among axon trajectories, arborization patterns and cytoarchitecture. Brain Res 393:109-120.

Gilmore EC, Herrup K (2000) Receiving Reelin. Curr Biol 10:R162-R166.

Gilmore EC, Ohshima T, Goffinet AM, Kulkarni AB, Herrup K (1998) Cyclin-dependent kinase 5-deficient mice demonstrate novel developmental arrest in cerebral cortex. J Neurosci 18:6370-6377.

Gogelia K, Hamori J (1992) Differential effects of long-term transplantation on the growth of cortical neurons containing parvalbumin or calbindin. Exp Brain Res 91:477-483.

Goldowitz D (1998) Scrambler chimeras confirm cell autonomous nature of the disabled mutation and offer insights into the migration process of cortical neurons. Soc Neurosci Abstr 24:1771.

Hatten ME, Liem RK, Mason CA (1986) Weaver mouse cerebellar granule neurons fail to migrate on wild-type astroglial processes in vitro. J Neurosci 6:2676-2683.

Hellmich MR, Pant HC, Wada E, Batty JF (1992) Neuronal cdc2-like kinase: a cdc-related protein kinase with predominately neuronal expression. Proc Natl Acad Sci USA 89:10867-10871.

Hendry SH, Jones EG, Emson PC, Lawson DE, Heizmann CW, Streit P (1989) Two classes of cortical GABA neurons defined by differential calcium binding protein immunoreactivities. Exp Brain Res 76:467-472.

Herrup K, Sunter K (1987) Numerical matching during cerebellar development: quantitative analysis of granule cell death in staggerer mouse chimeras. J Neurosci 7:829-836

Hiesberger T, Trommsdorff M, Howell B, Goffinet A, Mumby M, Cooper J, Herz J (1999) Direct binding of reelin to VLDL receptor and ApoE receptor 2 induces tyrosine phosphorylation of Disabled-1 and modulates tau phosphorylation. Neuron 24:481-489.

Hirotsune S, Takahara T, Sasaki N, Hirose K, Yoshiki A, Ohashi T, Kusakabe M, Murakami Y, Muramatsu M, Watanabe S, Nakao K, Katsuki M, Hayashizaki Y (1995) The reeler gene encodes a protein with an EGF-like motif expressed by pioneer neurons. Nat Genet 10:77-83.

Hirotsune S, Fleck MW, Gambello MJ, Bix GJ, Chen A, Clark GD, Ledbetter DH, McBain CJ, Wynshaw-Boris A (1998) Graded reduction of Pafah1b1 (Lis1) activity results in neuronal migration defects and early embryonic lethality. Nat Genet 19:333-339.

Howell BW, Hawkes R, Soriano P, Cooper JA (1997) Neuronal position in the developing brain is regulated by mouse disabled-1. Nature 389:733-737.

Howell BW, Herrick TM, Cooper JA (1999) Reelin-induced tyrosine phosphorylation of disabled 1 during neuronal positioning. Genes Dev 13:643-648.

Kwon Y, Tsai LW (1998) A novel disruption of cortical development in p35 (-/-) mice distinct from reeler. J Comp Neurol 395:510-522.

Landry CF, Pribyl TM, Ellison JA, Givogri MI, Kampf K, Campagnoni CW, Campagnoni AT (1998) Embryonic expression of the myelin basic protein gene: identification of a promoter region that targets transgene expression to pioneer neurons. J Neurosci 18:7315-7327.

Lemmon V, Pearlman AL (1981) Does laminar position determine the receptive field properties of cortical neurons? A study of corticotectal cells in area 17 of the normal mouse and the reeler mutant. J Neurosci 1:83-93.

Lew J, Beaudette K, Litwin CM, Wang JH (1992) Purification and characterization of a novel proline-directed protein kinase from bovine brain. J Biol Chem 267:13383-13390.

Magrassi L, Graziadei PP (1996) Lineage specification of olfactory neural precursor cells depends on continuous cell interactions. Brain Res Dev Brain Res 96:11-27.

Marin-Padilla M (1978) Dual origin of the mammalian neocortex and evolution of the cortical plate. Anat Embryol 152:109-126.

Matsubara M, Kusubata M, Ishiguro K, Uchida T, Titani K, Taniguchi H (1996) Site-specific phosphorylation of synapsin I by mitogen-activated protein kinase and $\mathrm{Cdk} 5$ and its effects on physiological functions. J Biol Chem 271:21108-21113.

Miller MW (1986) The migration and neurochemical differentiation of gamma-aminobutyric acid (GABA)-immunoreactive neurons in rat visual cortex as demonstrated by a combined immunocytochemicalautoradiographic technique. Brain Res 393:41-46.

Morest DK (1970) A study of neurogenesis in the forebrain of the opossum pouch young. Z Anat Entwickl Gesch 130:265-305.

Mortensen RM, Conner DA, Chao S, Geisterfer-Lowrance AA, Seidman JG (1992) Production of homozygous mutant ES cells with a single targeting construct. Mol Cell Biol 12:2391-2395.
Mullen RJ (1977) Site of pcd gene action and Purkinje cell mosaicism in cerebella of chimaeric mice. Nature 270:245-247.

Mullen RJ, Buck CR, Smith AM (1992) NeuN, a neuronal specific nuclear protein in vertebrates. Development 116:201-211.

Nadarajah B, Brunstrom JE, Grutzendler J, Wong RO, Pearlman AL (2001) Two modes of radial migration in early development of the cerebral cortex. Nat Neurosci 4:143-150.

Nikolic M, Dudek H, Kwon YT, Ramos YFM, Tsai LH (1996) The $\mathrm{cdk} 5 / \mathrm{p} 35$ kinase is essential for neurite outgrowth during neuronal differentiation. Genes Dev 10:816-825.

Nikolic M, Chou MM, Lu W, Mayer BJ, Tsai LH (1998) The p35/Cdk5 kinase is a neuron-specific Rac effector that inhibits Pak1 activity. Nature 395:194-198.

Nowakowski RS, Rakic P (1979) The mode of migration of neurons to the hippocampus: a Golgi and electron microscopic analysis in foetal rhesus monkey. J Neurocytol 8:697-718.

Nowakowski RS, Lewin SB, Miller MW (1989) Bromodeoxyuridine immunohistochemical determination of the lengths of the cell cycle and the DNA-synthetic phase for an anatomically defined population. J Neurocytol 18:311-318.

Ogawa M, Miyata T, Nakajima K, Yagyu K, Seike M, Ikenaka K, Yamamoto H, Mikoshiba K (1995) The reeler gene-associated antigen on Cajal-Retzius neurons is a crucial molecule for laminar organization of cortical neurons. Neuron 14:899-912.

Ohshima T, Ward JM, Huh CG, Longenecker G, Veeranna, Pant HC, Brady RO, Martin LJ, Kulkarni AB (1996) Targeted disruption of the cyclin-dependent kinase 5 gene results in abnormal corticogenesis, neuronal pathology and perinatal death. Proc Natl Acad Sci USA 93:11173-11178.

Ohshima T, Gilmore EC, Herrup K, Brady RO, Kulkarni AB (1998) Ontogeny of abnormal brain development in Cdk5(-/-) mice. Dev Brain Dys 10:271-281.

Ohshima T, Gilmore EC, Longenecker G, Jacobowitz DM, Brady RO, Herrup K, Kulkarni AB (1999) Migration defects of cdk5(-/-) neurons in the developing cerebellum is cell autonomous. $\mathrm{J}$ Neurosci 19:6017-6026.

Ohshima T, Ogawa M, Veeranna, Hirasawa M, Longenecker G, Ishiguro K, Pant HC, Brady RO, Kulkarni AB, Mikoshiba K (2001) Synergistic contributions of cyclin-dependant kinase 5/p35 and Reelin/Dab1 to the positioning of cortical neurons in the developing mouse brain. Proc Natl Acad Sci USA 98:2764-2769.

Paglini G, Pigino G, Kunda P, Morfini G, Maccioni R, Quiroga S, Ferreira A, Caceres A (1998) Evidence for the participation of the neuron-specific CDK5 activator P35 during laminin-enhanced axonal growth. J Neurosci 18:9858-9869.

Parnavelas JG (2000) The origin and migration of cortical neurones: new vistas. Trends Neurosci 23:126-131.

Qi Z, Tang D, Zhu X, Fujita DJ, Wang JH (1998) Association of neurofilament proteins with neuronal $\mathrm{Cdk} 5$ activator. J Biol Chem 273:2329-2335.

Rakic P (1971a) Neuron-glia relationship during granule cell migration in developing cerebellar cortex. A Golgi and electron microscopic study in Macacus Rhesus. J Comp Neurol 141:283-312.

Rakic P (1971b) Guidance of neurons migrating to the fetal monkey neocortex. Brain Res 33:471-476.

Rakic P (1972) Mode of cell migration to the superficial layers of fetal monkey neocortex. J Comp Neurol 145:61-83.

Reiner O, Carrozzo R, Shen Y, Wehnert M, Faustinella F, Dobyns WB, Caskey CT, Ledbetter DH (1993) Isolation of a Miller-Dieker lissencephaly gene containing $\mathrm{G}$ protein beta-subunit-like repeats. Nature 364:717-721.

Rezai Z, Yoon CH (1972) Abnormal rate of granule cell migration in the cerebellum of "Weaver" mutant mice. Dev Biol 29:17-26.

Rice D, Curran T (1999) Mutant mice with scrambled brains: understanding the signaling pathways that control cell positioning in the CNS. Genes Dev 13:2758-2773.

Rice DS, Sheldon M, D’Arcangelo G, Nakajima K, Goldowitz D, Curran T (1998) Disabled-1 acts downstream of Reelin in a signaling pathway that controls laminar organization in the mammalian brain. Development 125:3719-3729.

Senzaki K, Ogawa M, Yagi T (1999) Proteins of the CNR family are multiple receptors for Reelin. Cell 99:635-647.

Sheldon M, Rice DS, D’Arcangelo G, Yoneshima H, Nakajima K, Mikoshiba K, Howell BW, Cooper JA, Goldowitz D, Curran T (1997) Scrambler and yotari disrupt the disabled gene and produce a reelerlike phenotype in mice. Nature 389:730-733.

Sheppard AM, Pearlman AL (1997) Abnormal Reorganization of preplate neurons and their associated extracellular matrix: an early manifestation of altered neocortical development in the reeler mutant mouse. J Comp Neurol 378:173-179.

Shuang R, Zhang L, Fletcher A, Groblewski GE, Pevsner J, Stuenkel EL (1998) Regulation of Munc-18/syntaxin 1A interaction by cyclindependent kinase 5 in nerve endings. J Biol Chem 273:4957-4966. 
Simmons PA, Lemmon V, Pearlman AL (1982) Afferent and efferent connections of the striate and extrastriate visual cortex of the normal and reeler mouse. J Comp Neurol 211:295-308.

Soriano P, Jaenisch R (1986) Retroviruses as probes for mammalian development: allocation of cells to the somatic and germ cell lineages. Cell 46:19-29.

Tamamaki N, Fujimori KE, Takauji R (1997) Origin and route of tangentially migrating neurons in the developing neocortical intermediate zone. J Neurosci 17:8313-8323.

Trommsdorff M, Gotthardt M, Hiesberger T, Shelton J, Stockinger W, Nimpf J, Hammer RE, Richardson JA, Herz J (1999) Reeler/ Disabled-like disruption of neuronal migration in knockout mice lacking the VLDL receptor and ApoE receptor 2. Cell 97:689-701.

Tsai LH, Takahashi T, Caviness Jr VS, Harlow E (1993) Activity and expression pattern of cyclin-dependent kinase 5 in the embryonic mouse nervous system. Development 119:1029-1040.

Van Brederode JF, Mulligan KA, Hendrickson AE (1990) Calcium- binding proteins as markers for subpopulations of GABAergic neurons in monkey striate cortex. J Comp Neurol 298:1-22.

Ware ML, Fox JW, Gonzalez JL, Davis NM, Lambert de Rouvroit C, Russo CJ, Chua Jr SC, Goffinet AM, Walsh CA (1997) Aberrant splicing of a mouse disabled homolog, mdab1, in the scrambler mouse. Neuron 19:239-249.

Xiong W, Pestell R, Rosner MR (1997) Role of cyclins in neuronal differentiation of immortalized hippocampal cells. Mol Cell Biol 17:6585-6597.

Yuasa S, Kituh J, Kawamura K (1994) Interaction between growing thalamocortical afferent axons and the neocortical primordium in normal and reeler mice. Anat Embryol 190:137-154.

Zambrowicz BP, Imamoto A, Fiering S, Herzenberg LA, Kerr WG, Soriano P (1997) Disruption of overlapping transcripts in the ROSA beta geo 26 gene trap strain leads to widespread expression of betagalactosidase in mouse embryos and hematopoietic cells. Proc Natl Acad Sci USA 94:3789-3794. 